\title{
Roadmap to a RESTART
}

In the next seven chapters, we introduce the RESTART framework and its seven components. The letters in the acronym RESTART each represent one characteristic of more sustainable business models. In the seven chapters associated with each letter of the acronym, we will argue that the following seven characteristics are central to sustainable business model innovation that can lead to a RESTART. In the following, we briefly introduce each of the seven components of the framework and their corresponding chapters.

The necessary changes will not take place unless companies make them happen, and they will hardly be possible to achieve without substantial redesign of current business models. Standstill is not an option when the world is moving, and redesign of business models is therefore essential. Moreover, business model innovation appears to become both more frequent and more important in order to keep up with competitive pressures (Johnson et al. 2008; Mitchell and Coles 2003). In Chap. 5 , Redesign rather than standstill, we discuss what a business model is and how business models can be redesigned to ensure innovation with regard to how the company creates value for customers and thereby achieves profitability. 
Although significant changes are necessary, they will not be done overnight and companies cannot risk everything on one endeavor. Instead, they should move forward in a controlled manner and with an experimental mindset in order to find out what works and how new business models can function over time. Rather than doing a sudden turnaround, experimentation is therefore necessary (e.g., List and Gneezy 2014; Andries et al. 2013). In Chap. 6, Experimentation rather than turnaround, we show the importance of experimentation for the success of business model innovations in general and for sustainable business model innovations in particular.

An important step toward more efficient use of resources is to move beyond the notion that the customer needs ownership of products. Such a product-logic has dominated companies' offerings to customers, but companies are instead increasingly embracing a service-logic to promote sustainable business. This involves thinking in terms of access and functionality rather than ownership and designing services that are equally attractive to the customer as a product that can be bought and owned (e.g., Bocken et al. 2014; Baines et al. 2009). In Chap. 7, Service-logic rather than product-logic, we show how applying service-logic can contribute to smarter and more resource-efficient consumption that can reduce waste and pollution.

One of the most important changes needed to achieve a sustainable future is the smarter use of the scarce resources we have available. This means that we have to move away from the linear "take, make and dispose" approach upon which traditional business economics is based. Instead, companies should build circular business models based on reuse, resource efficiency and closed loops (e.g., Bocken et al. 2016; McDonough and Braungart 2009; Webster 2015). The circular economy is thus a key for greener and more efficient business. In Chap. 8, The circular rather than the linear economy, we look at how circular business models are central to the transition to a greener, smarter economy.

Being successful with changes of this magnitude requires collaboration. When considering the sustainability of companies' business models, it is too limiting to look solely at what goes on within the walls of the individual company. Achievements of this kind are difficult to reach through solo-runs, but rather requires appropriate alliances between 
companies, which together can solve problems they would not be successful in resolving alone (e.g., Kiron et al. 2015; Tencati and Zsolnai 2009; Chesbrough 2006). In Chap. 9, Alliances rather than solo-runs, we discuss the role alliances play in enabling sustainable innovations that span across organizations.

Implementing the comprehensive changes that lead to sustainable business requires prioritization. This implies that one cannot do everything and that it is more important to do the right thing than to do what looks good. For a sustainable future to be possible, it is not sufficient that companies conduct indulgences. Instead, companies should deliver results, that is, succeeding in making sustainability improvements that actually make a difference and that solve the important problems (e.g., Khan et al. 2016; Eccles and Serafeim 2013). In Chap. 10, Results rather than indulgences, we look at how sustainability performance can be achieved and how it can be aligned with financial performance.

To succeed with a transition of this caliber, the entire organization must be designed in a way that makes all organizational members pull in the right direction. Sustainable business models involve an intimate interplay between social, environmental and financial performance, and this must be reflected in goal structures, measurements and indicators, incentives, rewards and organization design in general (e.g., Jørgensen and Pedersen 2015; Schaltegger 2011; Gond et al. 2012; Figge et al. 2002). It involves moving from a one-dimensional emphasis on financial performance toward designing the entire organization for three-dimensionality. In Chap. 11, Three-dimensionality rather than one-dimensionality, we show how objectives, priorities, measurement and reporting are key elements to achieve sustainability and profitability.

We have now drawn up the roadmap for a RESTART. In the next seven chapters, we discuss each of the seven components of the RESTART framework in order to shed light on the types of business model innovation it proposes (Fig. 4.1). 


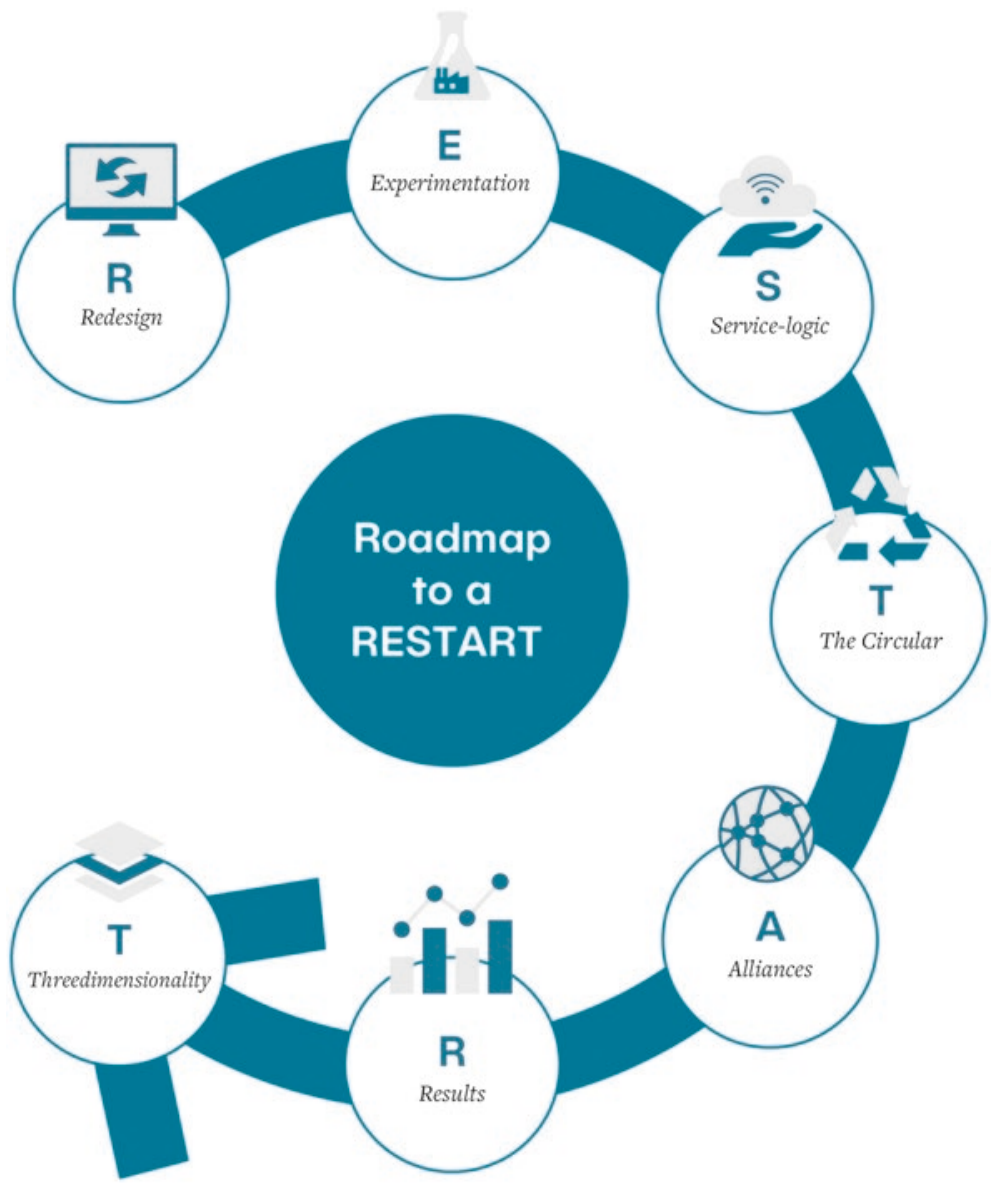

Fig. 4.1 A roadmap to RESTART

\section{References}

Andries, P., Debackere, K., \& Looy, B. (2013). Simultaneous experimentation as a learning strategy: Business model development under uncertainty. Strategic Entrepreneurship Journal, 7(4), 288-310.

Baines, T. S., Lightfoot, H. W., Benedettini, O., \& Kay, J. M. (2009). The servitization of manufacturing: A review of literature and reflection on future challenges. Journal of Manufacturing Technology Management, 20(5), 547-567. 
Bocken, N. M., de Pauw, I., Bakker, C., \& van der Grinten, B. (2016). Product design and business model strategies for a circular economy. Journal of Industrial and Production Engineering, 33(5), 308-320.

Bocken, N. M. P., Short, S. W., Rana, P., \& Evans, S. (2014). A literature and practice review to develop sustainable business model archetypes. Journal of Cleaner Production, 65, 42-56.

Chesbrough, H. W. (2006). Open innovation: The new imperative for creating and profiting from technology. Cambridge, MA: Harvard Business Press.

Eccles, R. G., \& Serafeim, G. (2013). The performance frontier. Harvard Business Review, 91(5), 50-60.

Figge, F., Hahn, T., Schaltegger, S., \& Wagner, M. (2002). The sustainability balanced scorecard-linking sustainability management to business strategy. Business Strategy and the Environment, 11(5), 269-284.

Gond, J. P., Grubnic, S., Herzig, C., \& Moon, J. (2012). Configuring management control systems: Theorizing the integration of strategy and sustainability. Management Accounting Research, 23(3), 205-223.

Johnson, M. W., Christensen, C. M., \& Kagermann, H. (2008). Reinventing your business model. Harvard Business Review, 86(12), 57-68.

Jørgensen, S., \& Pedersen, L. J. T. (2015). Responsible and profitable: Strategies for sustainable business models. Oslo: Cappelen Damm Akademisk.

Khan, M., Serafeim, G., \& Yoon, A. (2016). Corporate sustainability: First evidence on materiality. Accounting Review, 91(6), 1697-1724.

Kiron, D., Kruschwitz, N., Haanaes, K., Reeves, M., Fuisz-Kehrbach, S. K., \& Kell, G. (2015). Joining forces: Collaboration and leadership for sustainability. MIT Sloan Management Review, 56(3), 1-31.

List, J., \& Gneezy, U. (2014). The why axis: Hidden motives and the undiscovered economics of everyday life. New York, NY: Random House.

McDonough, W., \& Braungart, M. (2009). Cradle to cradle: Remaking the way we make things. North Point Press.

Mitchell, D., \& Coles, C. (2003). The ultimate competitive advantage of continuing business model innovation. Journal of Business Strategy, 24(5), 15-21.

Schaltegger, S. (2011). Sustainability as a driver for corporate economic success: Consequences for the development of sustainability management control. Society and Economy, 33(1), 15-28.

Tencati, A., \& Zsolnai, L. (2009). The collaborative enterprise. Journal of Business Ethics, 85(3), 367-376.

Webster, K. (2015). The circular economy: A wealth of flows. Coew, UK: Ellen MacArthur Foundation Publishing. 
Open Access This chapter is licensed under the terms of the Creative Commons Attribution-NonCommercial-NoDerivatives 4.0 International License (http:// creativecommons.org/licenses/by-nc-nd/4.0/), which permits any noncommercial use, sharing, distribution and reproduction in any medium or format, as long as you give appropriate credit to the original author(s) and the source, provide a link to the Creative Commons license and indicate if you modified the licensed material. You do not have permission under this license to share adapted material derived from this book or parts of it.

The images or other third party material in this chapter are included in the chapter's Creative Commons license, unless indicated otherwise in a credit line to the material. If material is not included in the chapter's Creative Commons license and your intended use is not permitted by statutory regulation or exceeds the permitted use, you will need to obtain permission directly from the copyright holder.

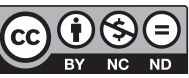

